\title{
Changes of Microbial Spoilage Indices Beluga Caviar Processed (Huso Huso) During Storage at $-2^{\circ} \mathrm{C}$
}

\author{
Afshin Fahim*, Ali Asghar Khanipour, Ghorban Zare Gashti \\ Department of Fish Processing Research / Iranian Fisheries Science Research Institute, Inland Waters Aquaculture Research Center, \\ Agricultural Research Education and Extension Organization (Areeo), Bandar Anzali, Iran
}

Email address:

Fshnfahim@yahoo.com (A. Fahim)

${ }^{*}$ Corresponding author

\section{To cite this article:}

Afshin Fahim, Ali Asghar Khanipour, Ghorban Zare Gashti. Changes of Microbial Spoilage Indices Beluga Caviar Processed (Huso Huso) During Storage at $-2^{\circ}$ C. Agriculture, Forestry and Fisheries. Vol. 7, No. 1, 2018, pp. 36-38. doi: 10.11648/j.aff.20180701.15

Received: September 5, 2017; Accepted: September 26, 2017; Published: March 5, 2018

\begin{abstract}
Beluga caviar processed microbial spoilage index changes (Huso huso) under the temperature of $-2{ }^{\circ} \mathrm{C}$ for twenty days were examined. The results showed that with increasing storage time of mesophilic bacteria, coliform and cool significantly reduced. The mean (SD) of mesophilic bacteria from $5.4 \pm 0.14 \mathrm{CFU} / \mathrm{g}$ at the time of production to $3.1 \pm 0.14$ $\mathrm{CFU} / \mathrm{g}$, The microorganisms coliform from $2.1 \pm 0.14$ during the production to $1.3 \pm 0.14$ and the cooling microorganisms from $2.8 \pm 0.14$ to $1.6 \pm 0.14$ was twenty days of cold storage. Quality rating microbial indicators are significantly during storage has been declining. The results showed that although a significant reduction indices mesophilic bacterium, coliform and cool during a period of twenty days at a temperature of $-2^{\circ} \mathrm{C}$, processed caviar is still away and will be accepted limit.
\end{abstract}

Keywords: Processed Caviar, Beluga, Microorganisms Total Count, Coliform Microorganisms

\section{Introduction}

Sturgeon, the family of Acipenseri formes, are known as the producers of caviar, which today is one of the most highly valued animal products in trade (Pikitch et al., 2005). One kilogram of Beluga caviar (H. huso), the most highly prized caviar, was sold for up to US\$ 4,290 on Western markets in 2005 . The following 27 species are included in the family of Acipenseriformes: 25 sturgeon species (Acipenserbaerii, A. brevirostrum, A. dabryanus, A. fulvescens, A. gueldenstaedtii, A. medirostris, A. mikadoi, A. naccarii, A. nudivendris, A. oxyrinchus, A. persicus, A. ruthenus, A. schrenckii, A. sinensis, A. stellatus, A. sturio, A. transmontanus, Husohuso, H. dauricus, Pseudoscaphirhynchuskaufmanni, $P$. hermanni, $P$. fedtschenkoi, Scaphirhynchus albus, S. platorynchus, and $S$. suttkusi), and two paddlefishes (Polyodon spathula, Psephurus gladius). However only 14 of these species are commercially important (highlighted in bold). Sturgeon and paddlefish species are widespread, occurring in Eurasia and North America. The high economic value of sturgeons, mainly for the caviar they produce, and the failure to manage harvests at a sustainable level, in combination with the loss of spawning grounds, have resulted in population declines. Today, all but three species are considered to be threatened by IUCN, with some believed to be on the brink of extinction. Caviar is the most popular and well-known processed edible fish roe product in wide demand all around the world. The term caviar refers to some of the processed fish roes and is an expensive product high in nutrients particularly the Vitamins [2]. Sturgeon caviar is one of the most exclusive and expensive fishery products and this is increasing because of increasing interest and tremendous over-fishing of commercial sturgeon species [4] there are more than 20 species of sturgeon harvest for caviar [1]. To obtain good caviar a great deal of skills are required Nowadays different procedures exist from the more traditional to the industrial ones. Most caviar is produced in Russia and Iran by sturgeon fish harvested from the Caspian Sea, Black Sea, and Sea of Azov. Caviar can be classified as: "Beluga" Obtained from Huso huso and caviar with coarse grained, black or dark gray, "Osetra" Prepared by Acipenser 
gueldenstaedtii colchicus (Russian Strugeon) and fine grained gray green or brown color caviar that is lighter than beluga and Sevruga Product is processed by Acipenser stellatus. The sevruga is smallest grains of greenish black [7]. There are more than 20 species of sturgeon harvested for caviar [1] Caviar is marketed through buyers who sell to exclusive restaurants, luxurious shops and mail-order retail outlets. The major problem for producers is to protect the raw material (roe samples) from spoilage by following clean working procedures. Freezing, various preservatives and packaging of caviar in anaerobic atmosphere are all methods that can help to limit spoilage of caviar. In addition to the salting process, freezing, smoking, canning, and sausage production technologies are also used in caviar production [7].

\section{Method}

\subsection{Sample Pre-preparation}

First, egg sacs were rinsed using clean water to remove adherent particles and impurities, prior to preparation of samples. Manual screening was followed to prepare the samples. The eggs were removed from the sac manually and separated from the connective tissue that surrounds them. There after the blood, connective tissues and other wastes on the roe were removed within 15 minutes while keeping eggs in $5 \%$ brine solution.

\subsection{Preliminary Trial}

Caviar processing was carried out by using 'dry- salting' method. Then the surface moisture of the roe was removed with the help of a clean cloth. Iodized powder form salt packets were used in the study. Fish roe samples were put in plastic containers with one layer of salt and one layer of roe alternatively in dry-salting method. The best ratios of salt: fish roe were determined using different ratios in the preliminary study. Similar weight of fish roe samples $(250 \mathrm{~g})$ were used for each trial and they were put in plastic trays with alternative salt layers keeping top and bottom layers as salt layer.

\subsection{Statistical Analysis}

Statistical analysis of the resulting data was performed with SPSS 19 software, so the normal distribution of data, the results of this test for statistical data analysis was used to test treatments. To evaluate the impact of dwell time in the nutritional value and the index changes microbial treatments to And the presence or absence of a significant difference between the values of each index at 95 percent Two-way analysis of variance methods to compare means and meaningful treatments known cases where the ensemble Duncan test was used.

\section{Result}

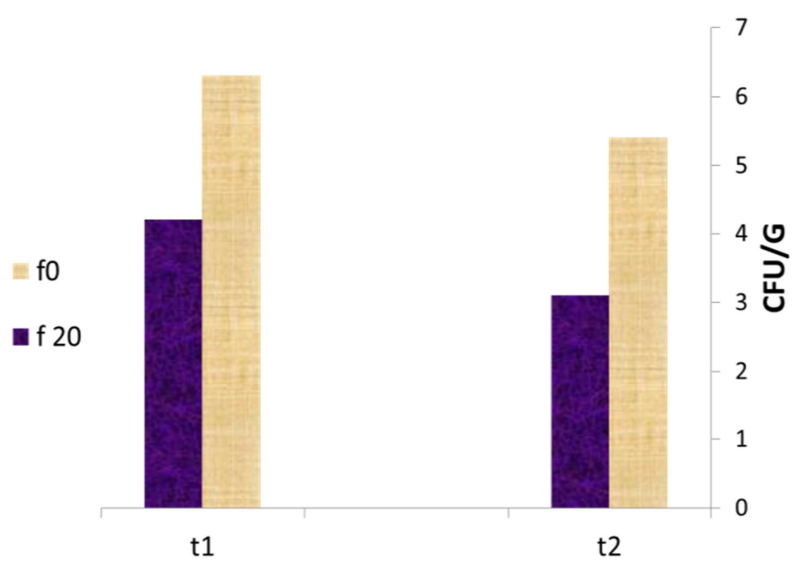

Figure 1. Results of the Total Plate Count (TPC) for final products in 20 days.

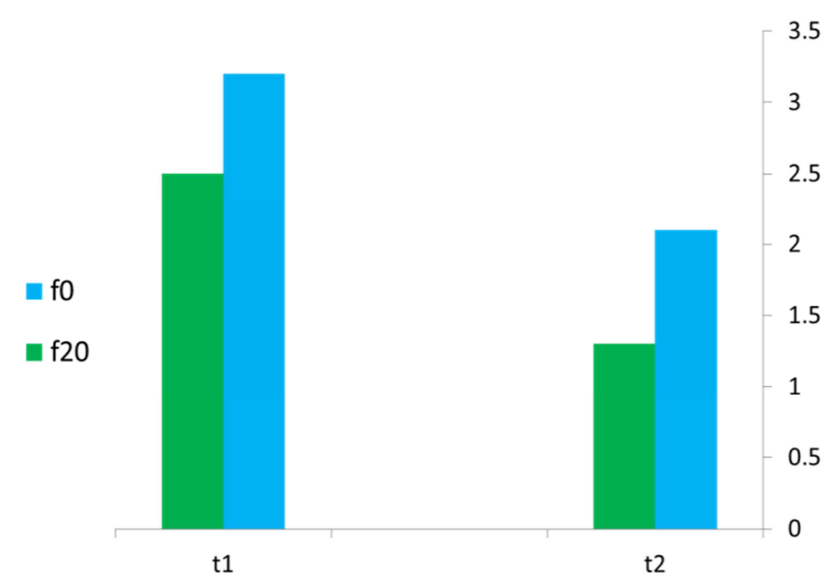

Figure 2. Results of the coliform Count for final products in 20 days.

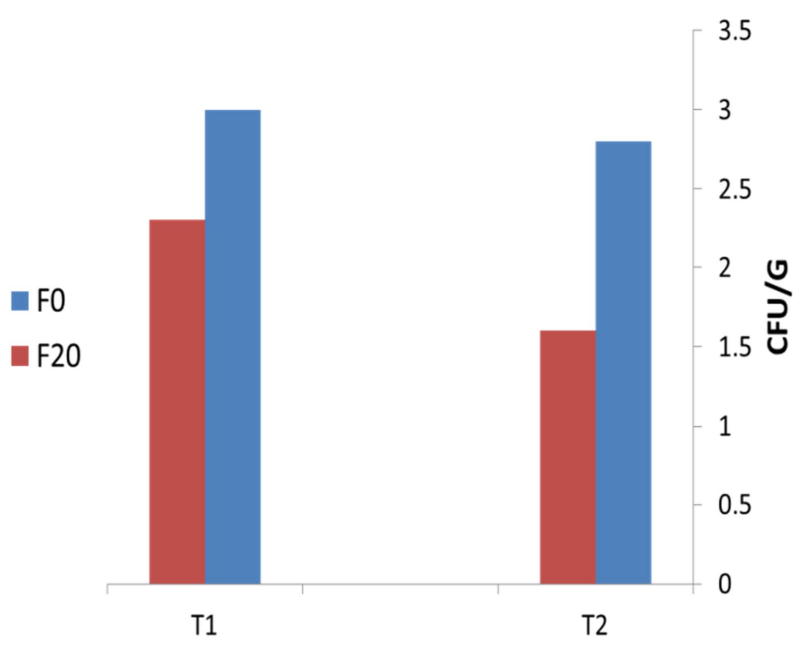

Figure 3. Results of the pseudomonas Count for final products in 20 days.

Total coliform and pseudomonas count were significant in all 02 products. Our research findings indicated that all final products are pathogenic free products up to twenty days period. Average values of the Total Plate Count (TPC) are given in Figure 1 for approximately twenty days of storage 
time period. Accordingly Treatment 02 records lowest TPC value for a period of twenty days.

Total Plate Count (TPC) was determined using plate cultures on nutrient agar following incubation at $37^{\circ} \mathrm{C}$ for a period of $48 \mathrm{hrs}$. General Coliform and E.coli presence were examined at incubation temperature of $37^{\circ} \mathrm{C}$. The caviar samples were analyzed once in 14 days for twenty days of storage for their microbiological aspects

\section{Discussion}

Total Plate Count (TPC) was determined using plate cultures on nutrient agar following incubation at $37^{\circ} \mathrm{C}$ for a period of $48 \mathrm{hrs}$. General Coliform and E.coli presence were Total coliform and E. coli count were Significant in all treatment products.Our research findings indicated that all final products are pathogenic free products up to two month period. Average values of the Total Plate Count (TPC) are given in Figure 1 for approximately 20 days of storage time period. Accordingly Treatment 02 records lowest TPC value for a period of 20 days Coliform bacteria indicate the likely presence of pathogenic (disease-causing) bacteria or viruses including E.coli. They are present in the intestinal tracts of all warm-blooded animals, including humans. Our research findings revealed that all final products are not pathogenic up to 20 days period. Coliform contamination in caviar was detected [9]. It means that results of our study are analogous to their findings. Microbial growth and metabolism is a major cause of fish spoilage which produce amines, biogenic amines such as putrescence, histamine and cadaverine, organic acids, sulphides, alcohols, aldehydes and ketones with unpleasant and unacceptable off-flavors [8]. For the growth of every microorganism, optimum moisture content is an essential factor same like $\mathrm{pH}$ and temperature. Salt content declines the moisture level of the product and creates a toxic condition for microbial populations there is an inverse relationship between applied salt level and moisture percentage of the product. So with increasing salt level, moisture content of the product reduces rapidly and inhibits the favorable condition for microorganisms. Total Coliform Count has increased with the time period due to the propagation of coliforms in all treatments within given period. In Sri Lanka, quality standards have not been yet recommended for fish roe based processed products. When compared with the Sri Lanka standard specification (2007) for salted, dried fish, all 02 final products of our study were always at accepted standard level $(<100 \mathrm{TPC} / \mathrm{g})$ for the period of study.

\section{Conclusion}

Production cost of Treatment 02 is the highest, since this treatment requires highest salt percentage for processing. microbial count is lowest for storage time period, Treatment 01 is not concerned as the best treatment. Treatment 02 requires intermediate salt amount for processing. Therefore production cost of Treatment 02 can be relatively low. As well as nutritional composition and consumer preference for Treatment 02 is not in satisfactory level compared with Treatment 01 . Treatment 02 is also accepted as best treatment for processing of simulated caviar.

\section{References}

[1] M. Al-Holy, Y. Wang, J. Tang and B. Rasco, B. "Dielectric properties of salmon (Oncorhynchus keta) and sturgeon (Acipenser transmontanus) caviar at radio frequency (RF) and microwave (MW) pasteurization frequencies", Journal of Food Engineering, 2005, 70: pp. 564- 570.

[2] G. Altug, and Y. Bayrak, Microbiological analysis of caviar from Russia and Iran", Food Microbiology. 2003, 20: pp. 8386. Doi: 10.1016/S0740-0020(02)000904.

[3] AOAC. Official Methods of Analysis of the Association of Analytical Chemist, 15.

[4] Wolf, C., Hübner, P. and Lüthy, J. (1999) Differentiation of sturgeon species by PCR-RFLP. Food Research International 32: 699-705.

[5] P. H. L. Dalgaard, N. Madsen, N. Samieian, and J. Emborg, "Biogenic amine formation and microbial spoilage in chilled garfish (Belone belone) effect of modified atmosphere packaging and previous frozen storage", J. Applied Microbiol. 2006, 101: pp. 80-95. DOI: 10.1111/j.1365-2672.2006.02905.

[6] L. Gram, and P. Dalgaard, "Fish spoilage bacteria problems and solutions", Current Opinion Biotechnology., 2002, 13: pp. 262-266. DOI: 10.1016/S0958-1669(02)00309-9.

[7] A. G. Inanli, O. E. Coban and M. Dartay, "The chemical and sensorial changes in rainbow trout caviar salted in different ratios during storage", Fish Sci., 2010, 76: pp. 879-883 DOI 10.1007/s12562-010-0279-6.

[8] J. Emborg, B. G. Laursenand, and P. Dalgaard "Significant histamine formation in tuna (Thunnus albacares) at $2^{\circ} \mathrm{C}$ : Effect of vacuum-and modified-atmosphere-packaging on psychrotolerant bacteria", Int. J. Food Microbiol.1, 2005, 01 :pp. 263-279. Doi: 10.1016/ j.ijfoodmicro. 2004.12.001.

[9] B. H. Himelbloom, and C. A. Crapo, "Microbial evaluation of Alaska salmon caviar", J Food Prot., 1998. 61(5):pp. 626-628

[10] AOAC. Official Methods of Analysis of the Association of Analytical Chemist, 15th edition, Washington DC, USA: 1990. 66-88. 